\title{
Identifikasi Pola Penyakit pada Citra Iris Mata dengan RBF Neural Network
}

\author{
Daniel Hadrian Yohandy ${ }^{1}$, I Made Nomo Wiranata ${ }^{2}$, Tea Qaula Ferbia ${ }^{3}$ \\ ${ }^{1}$ Universitas Atma Jaya Yogyakarta \\ e-mail: nverbe94@gmail.com \\ ${ }^{2}$ Universitas Atma Jaya Yogyakarta \\ e-mail: made.wiranata23@gmail.com \\ ${ }^{3}$ Universitas Atma Jaya Yogyakarta \\ e-mail: milandi.tea@gmail.com
}

\begin{abstract}
Abstrak
Gaya kehidupan manusia semakin beragam dan padat sehingga banyak terjadi dimana penyakit dan gangguan pada tubuh diketahui ketika sudah dalam kondisi parah. Kebanyakan manusia tidak disiplin dalam memantau kesehatan mereka karena dirasa belum ada cara yang mudah dan efisien, cara yang mayoritas digunakan adalah check-up ke rumah sakit. Iris mata manusia dapat menjadi salah satu media atau sarana dalam mengenali gangguan kondisi tubuh seseorang. Pola yang muncul pada iris mata dapat dikenali dengan bantuan teknologi jaringan saraf tiruan yang salah satunya adalah metode RBF yang dipakai dalam penelitian ini. Hasil yang ditemui pada penelitian ini adalah penggunaan metode RBF mampu untuk mengenali pola yang ada di iris mata, dan dapat memberikan hasil pengenalan penyakit kompleks dan stress dengan akurasi yang dibilang masih rata-rata (sekitar 50\%).
\end{abstract}

Kata Kunci: Penyakit, Iris Mata, Pola, $R B F$

\begin{abstract}
Human lifestyle is more diverse and dense, so much happening where disease and disturbance in the body are known when it is in severe condition. Most humans are not disciplined in monitoring their health because it feels there is no easy and efficient way, the way that the majority used is the check-up to the hospital. The iris of the human eye can be one of the media or means in recognizing a person's body condition disorder. Patterns that appear on the iris can be identified with the help of artificial neural network technology one of which is the RBF method used in this study. The results found in this study are the use of RBF method to recognize the existing pattern in the iris and can provide the results of the introduction of complex diseases and stress with an accuracy that is still fairly average (about 50\%).
\end{abstract}

Keywords: Disease, Eye Iris, Pattern, RBF

\section{Pendahuluan}

Kesehatan tubuh seseorang tergantung dari gaya hidup mereka baik dari aktivitas dan konsumsi pangan seharihari. Kesehatan adalah sesuatu yang sangat penting dalam kehidupan setiap orang, manusia yang sehat dapat melakukan lebih banyak hal di banding dengan manusia yang tidak sehat, sehingga setiap orang mendambakan tubuhnya selalu dalam keadaan sehat (Ramdan, n.d.). Faktor globalisasi dan kemajuan teknologi memicu meningkatnya penggunaan gadget dari waktu ke waktu (Hidayat \& Junianto, 2017). Hal tersebut memungkinkan terciptanya banyak kegiatan baru yang dulunya tidak dapat dilakukan. Aktivitas yang semakin padat membuat orang tidak begitu peka dan kurang memperhatikan kesehatan mereka hingga pada akhirnya terkena berbagai macam penyakit seperti contohnya stress dan penyakit kompleks lain dikarenakan gaya hidup yang tidak teratur. Usaha untuk menyembuhkan penyakit ketika sudah muncul terkadang sudah terlambat dan mengancam penderita jika yang muncul adalah penyakit berat. Penyakit berat didahului dengan tanda dan gejala tertentu, karena itu pengenalan dan pendeteksian 
dini sangat berguna untuk menghindari kemungkinan tersebut.

Iridologi adalah seni pengetahuan untuk mendeteksi penyakit spesifik tubuh manusia dari iris. Deteksi akan memberitahu setiap organ individu ketika memiliki kinerja rendah atau tinggi (tidak normal). Iris mengungkapkan perubahan kondisi dari setiap bagian tubuh. Setiap organ dan bagian tubuh diwakili dalam iris di daerah yang terdefinisi dengan baik (Passarella \& Fachrurrozi, 2013). Di dalam iridiologi terdapat bagan iridologi yang menunjukkan lokasi organ-organ pada tubuh manusia (Rochmad, 2009), sehingga dapat mendeteksi jika ada kemungkinan munculnya penyakit yang harus cepat diatasi. Namun saat ini iridologi masih banyak diterapkan secara manual dengan menggunakan pengamatan dan expertasi dokter. Teknik pengolahan citra digunakan untuk menerapkan teknologi ke sistem pengenalan pola yang akan dibuat berbasis desktop komputer.

Sudah ada beberapa penelitian sebelumnya yang terkait pola pada iris mata atau iridology. Salah satunya adalah penelitian yang dilakukan oleh Erwin dkk untuk mengidentifikasi gangguan pada usus besar (colon) dengan metode naïve bayes dengan akurasi 62.5\% (Erwin, Fachrurrozi, Passarella, \& Darmawahyuni, 2013), kemudian ada diagnosis gangguan ginjal menggunakan metode segmentasi berdasarkan deteksi tepi dengan akurasi 95\% (Noor, Rahayu, Isnanto, \& Hidayatno, n.d.) dan penelitian oleh Putri dkk pengunaan citra iris mata dengna metode Region of Interest untuk diagnose gangguan saraf (Wijayanti et al., 2017). Sulistiyo dkk dengan menggunakan LDA (Linear Discriminant Analysis) dan CCNA (Cascade Correlation Neural Network) terhadap penyakit Dyspepsia (Sulistiyo, 2014).

Sedangkan untuk penelitian di area biomedis yang menggunakan metode RBF sendiri juga sudah banyak dilakukan seperti penelitian model prediksi penyakit ginjal kronik yang dilakukan Stefanus dkk (Santosa, Widjanarko, \& Supriyanto, 2016). Metode RBF juga pernah digunakan untuk penelitian penentuan morfologi sel darah merah yang dilakukan oleh Zulkifli dkk (Tahir, Warni, Sylwana, \& Wahyuni, 2012). Metode RBF juga bisa digunakan untuk pengenalan pola seperti pengenalan wajah (Er, Wu, Lu, \& Toh, 2002).

\section{Metode Penelitian Iridologi}

Pengenalan pola iris memberikan banyak manfaat bagi mereka yang mempraktikkan iridologi untuk mendeteksi gejala berdasarkan pola di iris pasien. Dalam iridologi, ada banyak faktor di dalamnya analisis iris harus dipertimbangkan karena struktur iris yang rumit (Othman, 2010). Iridologi adalah ilmu yang mempelajari pola dan susunan serat di iris mata. Dengan melakukan pengamatan dan observasi terhadap pola tersebut, nantinya kita dapat menghubungkannya dengan masalahmasalah kesehatan tertentu pada seseorang. Pola di iris mata juga dapat menunjukkan kondisi tubuh seseorang misalnya status lemah atau kuat, tingkat kesehatan serta peralihan menuju keparahan atau proses penyembuhan $(\mathrm{H}$, Zahra, \& Isnanto, n.d.).

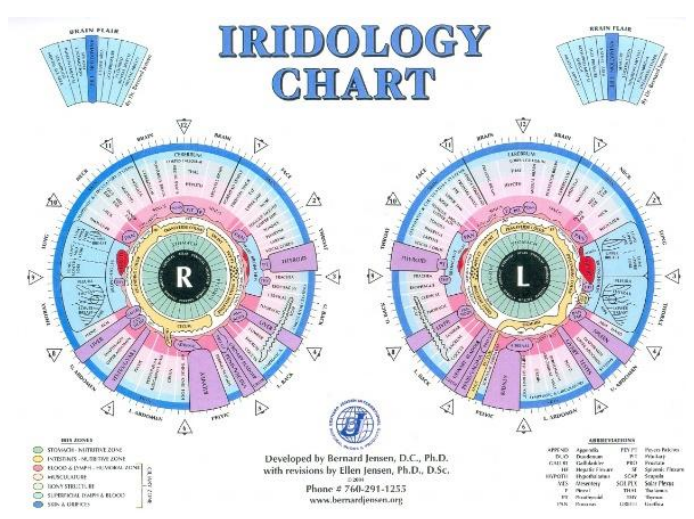

Gambar 1. Bagan Iridologi Bernard Jensen

Berdasarkan pola yang didapat, gejala penyakit dan tanda kesehatan tubuh seseorang dapat dilihat dengan cara membandingkan pola tersebut ke bagan iridologi yang dikembangkan oleh Bernard Jensen (Gambar 1).

\section{Radial Basis Function}

Sistem informasi jaringan syaraf tiruan (JST) digunakan untuk pengolahan data yang memiliki karakteristik kinerja tertentu, menirukan cara kerja otak manusia untuk menyelesaikan suatu masalah yang mana proses pembelajaran berdasarkan perubahan bobot sinapsisnya. JST dapat digunakan untuk memodelkan 
hubungan kompleks antara input dan output untuk dapat menemukan pola-pola pada data atau klasifikasi data melalui proses pembelajaran. Ada beberapa metode yang digunakan dalam jaringan syaraf tiruan, diantaranya adalah metode Radial Basis Function (RBF) (Azmi, Utara, \& Pola, 2016).

Penelitian fungsi RBF yang orisinil dilakukan oleh Powell dan yang lain selama tahun 1980-an. Dalam karya asli ini, fungsi dasar radial digunakan untuk interpolasi yang tepat dalam ruang multidimensi. Dalam kata lain, fungsi yang diciptakan oleh interpolasi dasar radial diperlukan untuk melewati semua target dalam set pelatihan (Hagan, Demuth, \& Beale, 1995).

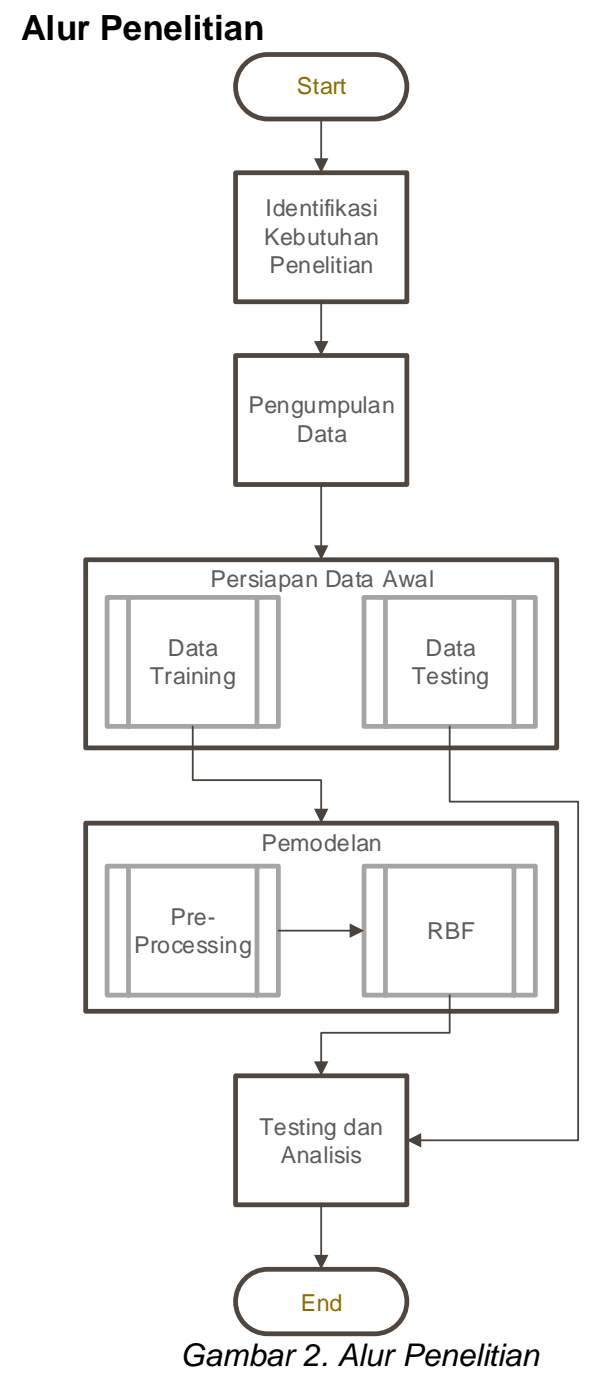

A. Identifikasi Kebutuhan Penelitian

Tahap ini dilakukan dengan pengumpulan informasi dan referensi dari penelitian terdahulu. Beberapa hal yang termasuk di kebutuhan penelitian adalah pembuatan alur penelitian, tempat dan sumber pengumpulan data citra iris mata, metode pelatihan pengenalan pola, dan uji coba pengenalan pola. Landasan teori dan pemahaman mengenai iris mata dan iridology akan dikonsultasikan dengan pakar atau dokter yang sudah memiliki pengalaman dalam menerapkan iridologi dengan banyak pasien. Metode penelitian yang digunakan adalah RBF.

\section{B. Pengumpulan Data}

Tahap ini dilakukan dengan mencari data citra iris mata dengan pakar atau dokter yang sudah berpengalaman dalam penerapan iridology. Untuk studi kasus ini, data citra iris mata diambil dari pasien klinik Intan di Yogyakarta, dengan meminta dari dokter yang bersangkutan. Adapun data citra mata yang didapat sebanyak 1.591 citra iris mata pasien di klinik Intan.

Pemilihan data yang dipakai sebagai data latihan dan uji coba dilakukan dengan manual yang diperkirakan dalam melambangkan citra iris mata pasien yang sehat, stress, dan memiliki penyakit kompleks. Pola yang dipakai sebagai target pengenalan dalam sistem ini adalah lingkaran putih pada iris mata sebagai penunjuk peredaran darah yang tidak lancar dan juga pola pada wilayah lingkaran iris mata untuk mendeteksi pola yang muncul sebagai penanda penyakit tertentu yang akan dibandingkan ke bagan iridologi Bernard Jensen untuk diketahui penyakitnya.

\section{Persiapan Data Awal}

Sebanyak 90 data citra yang terdiri dari 30 citra iris pasien sehat (normal), 30 citra pasien dengan pola lingkaran putih (peredaran darah tidak lancar), dan 30 citra pasien dengan pola selaput yang beragam yang menunjukkan penyakit kompleks. Setelah dikumpulkan, kemudian akan diuji coba sebagai data training citra iris mata sehat, pasien kondisi pembuluh darah tidak lancar, dan pasien dengan penyakit kompleks. Setelah itu akan diambil secara random sejumlah citra mata untuk digunakan dalam pengujian atau testing dari data awal namun tidak termasuk citra yang sudah dipakai. Dilakukan beberapa proses uji coba baik dalam pemilihat data training dan perlakuan dalam pengenalan pola untuk mencari metode terbaik dalam 
mengenali pola tanda penyakit pada iris mata.

\section{Pemodelan}

\section{Pre-processing Image resize}

Pada tahap ini dilakukan image resize untuk data image iris mata. Yang mana bertujuan untuk menyamaratakan ukuran dari data image iris mata (Gambar 3 \& 4).

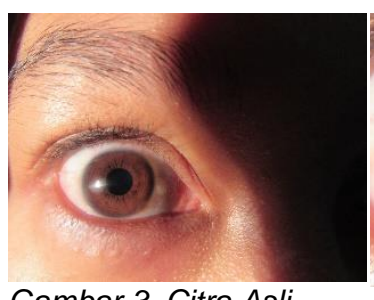

Gambar 3. Citra Asli

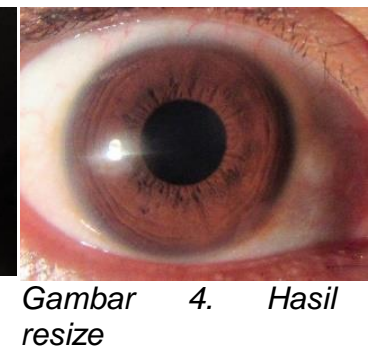

Image grayscale

Setelah dilakukan image resize, data image iris mata yang sebelumnya dalam bentuk rgb dikonversi kedalam bentuk grayscale atau abu-abu

\section{Pelatihan RBF}

Untuk menggunakan metode RBF, ada beberapa tahap yang harus dilakukan sebagai berikut (Muhammad Erwin Ashari Haryono, 2005).

\section{- Clustering Data}

Pada tahap awal data terlebih dahuu di-cluster atau dikelompokkan berdasarkan kemiripan kedekatan tertentu antara data satu dengan yang lainnya. Penentuan cluster dengan sendirinya akan menghasilkan center atau pusat dari kelompok data. Jumlah cluster menentukan hidden unit yang dipakai. Untuk melakukan clustering terdapat du acara. Cara yang pertama ialah menentukan center secara acak dari kelompok data. Cara yang kedua dengan menggunakan algoritma clustering, cara ini lebih baik dari cara yang pertama akan tetapi lebih sulit.

\section{- Pembaharuan bobot}

Pada tahap ini dilakukan perhitungan untuk memperbaharui atau memperbaiki nilai bobot. Pada tahap ini diperlukan nilai target sehingga bersifat supervised. Langkah-langkah pada tahap ini sebagai berikut

1. Meneruskan sinyal input ke hidden layer dan menghitung nilai fungsi aktivasinya pada tiap hidden layer menggunakan fungsi aktivasi

Gaussian. Rumus yang digunakan :

$\varphi\left(|| X_{m}-t_{i}||\right)=\exp \left(-1 / \sigma^{2}\left\|X_{m}-t_{i}\right\|^{2}\right)(2.1$.

$m=1,2,3, \ldots$ sesuai dengan jumlah training pattern

$\mathrm{i}=1,2,3, \ldots$ sesuai dengan jumlah

hidden unit

$\mathrm{X}$ merupakan vektor input

t merupakan vektor data yang dianggap sebagai center

2. Menyusun matriks Gaussian, dari hasil perhitungan pada langkah 1

$$
G=\left[\begin{array}{cccc}
\varphi_{11} & \varphi_{12} & \cdots & \varphi_{1 C} \\
\varphi_{21} & \varphi_{22} & \cdots & \varphi_{2 C} \\
\cdots & \cdots & \cdots & \cdots \\
\varphi_{41} & \varphi_{42} & \cdots & \varphi_{M C}
\end{array}\right]
$$

$$
\begin{aligned}
& \text { *) Kolom terakhir biasanya diisi nilai bias } \\
& *) \mathrm{M} \rightarrow \text { Vektor input ke } \mathrm{M} \\
& *) \mathrm{C} \rightarrow \text { Hidden unit ke-C }
\end{aligned}
$$

3. Menghitung bobot baru (W) dengan mengalikan pseudoinverse dari matriks $\mathrm{G}$, dengan vektor target (d) dari data training. Rumusnya:

$$
W=\left(G^{T} G\right)^{-1} G^{T} d
$$

Untuk menghitung nilai output dari jaringan, menggunakan rumus:

$$
\begin{aligned}
& y(x)=\sum_{i=1}^{2} w G(|| x=t t||)+b \\
& \mathrm{G}(\mathrm{x}) \text { pada rumus ini sama } \varphi(x)
\end{aligned}
$$

\section{Pengujian RBF}

Pada pengujian outputnya merupakan hasil perkalian dari bobot akhir dengan nilai matriks yang didapat. Rumus yang digunakan :

$\mathrm{Y}=\mathrm{w}_{1} * \mathrm{j}_{1}+\mathrm{w}_{2} * \mathrm{j}_{2}+$ bias

\section{E. Testing / Pengujian}

Pada tahap ini dilakukan pengujian untuk mengindentifikasi pola yang didapat pada suatu citra iris mata. Pengujian dilakukan terhadap 30 data citra iris mata yang sudah di resize. 


\section{Hasil dan Pembahasan}

Pada pengujian pertama dilakukan untuk menentukan nilai treshhold terbaik. Dimana saat pengujian menggunakan data uji sebanyak 30 image iris mata. Antarmuka hasil pengenalan pola pada aplikasi ditunjukkan pada gambar berikut:

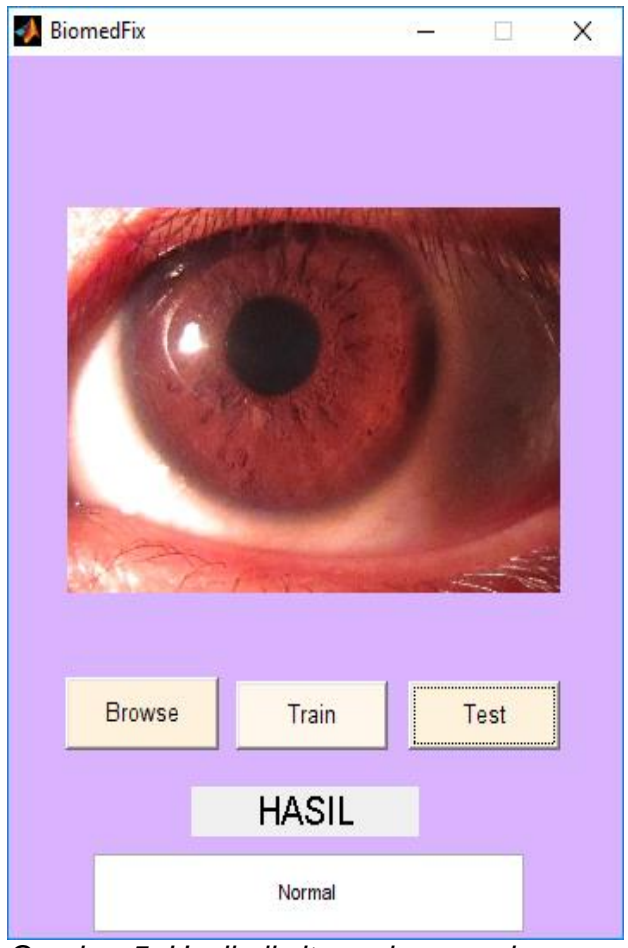

Gambar 5. Hasil uji citra pola normal

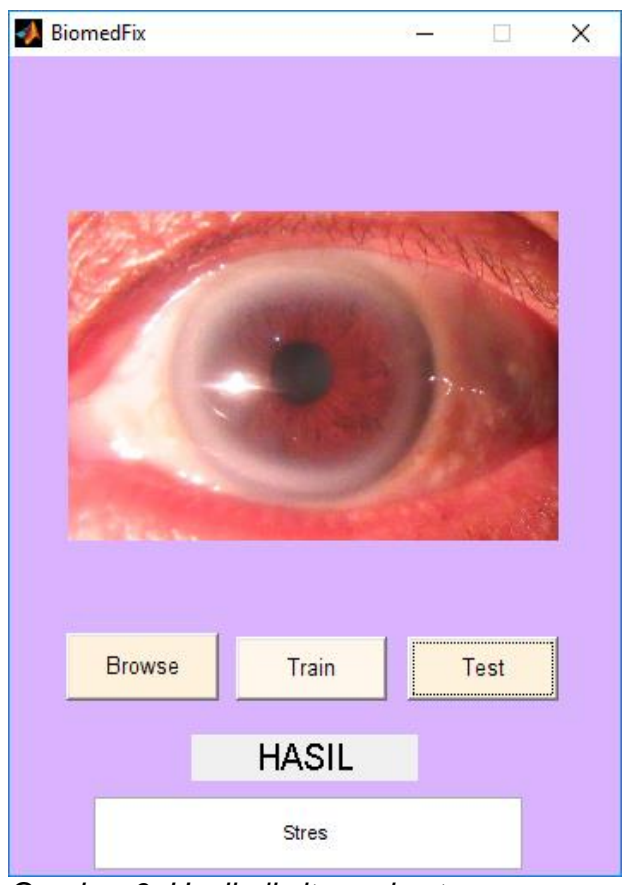

Gambar 6. Hasil uji citra pola stress

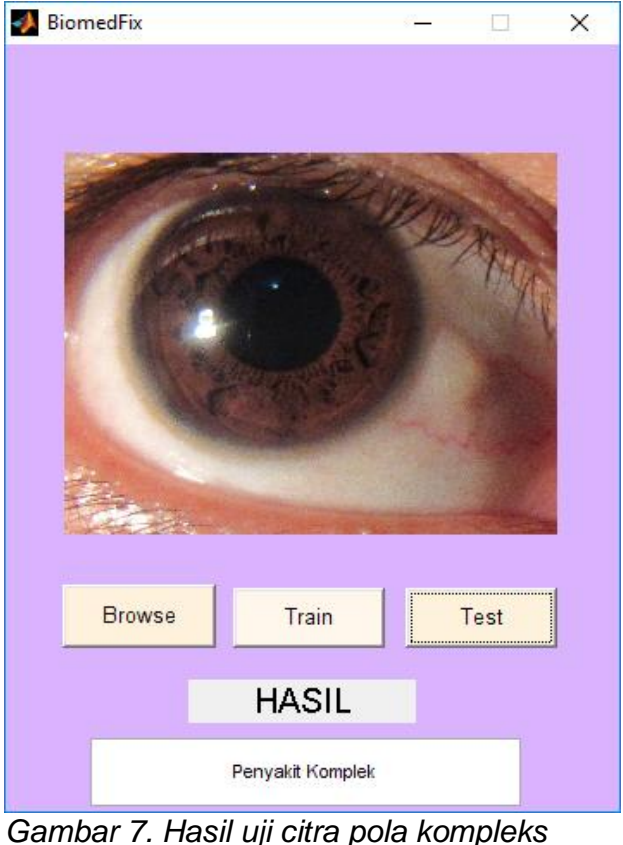

Hasil dari pengujian dapat dilihat pada table dibawah ini.

Table 1. Hasil pengujian untuk mencari nilai threshold terbaik

\begin{tabular}{|l|l|l|l|}
\hline No & Treshold & $\begin{array}{l}\text { Data yang } \\
\text { dikenali }\end{array}$ & Akurasi \\
\hline 1 & 0,5 & 14 & $46,67 \%$ \\
\hline 2 & 0,52 & 14 & $46,67 \%$ \\
\hline 3 & 0,55 & 14 & $46,67 \%$ \\
\hline 4 & 0,57 & 14 & $46,67 \%$ \\
\hline 5 & 0,6 & 14 & $46,67 \%$ \\
\hline 6 & 0,62 & 16 & $53,33 \%$ \\
\hline 7 & 0,65 & 15 & $50 \%$ \\
\hline 8 & 0,67 & 13 & $43,33 \%$ \\
\hline 9 & 0,7 & 14 & $46,67 \%$ \\
\hline
\end{tabular}

Dari table pengujian menunjukan bahwa dilakukan 9 kali pengujian untuk mendapatkan nilai threshold terbaik. Dari hasil pengujian tersebut mendapatkan nilai akurasi terendah pada nilai threshold 0,67 dengan akurasi sebesar 43,33\%. Sedangkan terbaik didapat pada nilai threshold 0,62 dengan akurasi sebesar $53,33 \%$.

Pada pengujian pkedua dilakukan untuk menentukan nilai sigma terbaik dimana nilai threshold yang digunakan berdasarkan hasil dari pengujian pertama. Pada pengujian kedua masih menggunakan data uji sebanyak 30 image iris mata. Hasil dari pengujian dapat dilihat pada table dibawah ini. 
Table 2. Hasil pengujian untuk mencari nilai threshold terbaik

\begin{tabular}{|l|l|l|l|l|}
\hline No & Sigma & Treshold & $\begin{array}{l}\text { Data } \\
\text { yang } \\
\text { dikenali }\end{array}$ & Akurasi \\
\hline 1 & 1 & 0,62 & 15 & $50 \%$ \\
\hline 2 & 2 & 0,62 & 16 & $53,33 \%$ \\
\hline 3 & 3 & 0,62 & 16 & $53,33 \%$ \\
\hline 4 & 4 & 0,62 & 16 & $53,33 \%$ \\
\hline 5 & 5 & 0,62 & 16 & $50 \%$ \\
\hline
\end{tabular}

Dari table pengujian menunjukan bahwa dilakukan 5 kali pengujian untuk mendapatkan nilai sigma terbaik. Dari hasil pengujian tersebut mendapatkan nilai akurasi terendah pada nilai sigma 1 dan 5 dengan akurasi sebesar $50 \%$. Sedangkan akurasi terbaik didapat pada nilai sigma 2 , 3 dan 4 dengan akurasi sebesar 53,33\%.

\section{Kesimpulan}

\section{Berdasarkan}

disimpulkan

hasi

hasil pengujian, menggunakan RBF belum memiliki akurasi yang tinggi. Penggunaan metode RBF masih dapat dipadukan dengan metode lain untuk meningkatkan akurasi pengenalan pola citra iris mata. Untuk penelitian selanjutnya diharapkan hasil dari penelitian ini dapat menjadi data pendukung dalam penggunaan metode RBF untuk mengenali pola kondisi tubuh seseorang pada citra iris mata.

\section{Referensi}

Azmi, F., Utara, U. S., \& Pola, P. (2016). Analisis Learning Jaringan Rbf ( Radial Basis Function Network ), V(2), 32-34.

Er, M. J., Wu, S., Lu, J., \& Toh, H. L. (2002). Face recognition with radial basis function (RBF) neural networks. IEEE Transactions on Neural Networks, 13(3), 697-710. https://doi.org/10.1109/TNN.2002.100 0134

Erwin, Fachrurrozi, M., Passarella, R., \& Darmawahyuni, A. (2013). Identifikasi gangguan usus besar (colon) berdasarkan citra iris mata menggunakan metode naïve bayes. In Seminar Nasional Matematika, Sain dan Teknologi (pp. 54-61).

H, R. G. A. N. P., Zahra, A. A., \& Isnanto, R. R. (n.d.). TIRUAN PERAMBATAN
BALIK.

Hagan, M. T., Demuth, H. B., \& Beale, M. H. (1995). Neural Network Design. Boston Massachusetts PWS, 2, 734. https://doi.org/10.1007/1-84628-303-5

Hidayat, A. R., \& Junianto, E. (2017). Pengaruh Gadget Terhadap Prestasi Siswa SMK Yayasan Islam Tasikmalaya Dengan Metode TAM | Hidayat | Jurnal Informatika. Jurnal Informatika, 4(2), 163-173. Retrieved from

http://ejournal.bsi.ac.id/ejurnal/index.p hp/ji/article/view/2096

Klinik Intan. (n.d.). Retrieved from http://www.klinikintanjogja.com/uc/doc torprofile.php

Muhammad Erwin Ashari Haryono. (2005). Pengenalan Huruf Menggunakan Model jaringan Saraf Tiruan RBF. Sains Komputer, 3(Snati).

Noor, D., Rahayu, P., Isnanto, R. R., \& Hidayatno, A. (n.d.). Tepi.

Othman, Z. (2010). Preliminary Study on Iris Recognition System: Tissues of Body Organs in Iridology, (December), 115-119.

Passarella, R., \& Fachrurrozi, M. (2013). Development of Iridology System Database for Colon Disorders Identification using Image Processing, 2(June), 100-103.

Ramdan, D. S. (n.d.). Deteksi region iris mata untuk menentukan kondisi kesehatan jantung.

Rochmad, M. (2009). MELALUI PENGENALAN POLA IRIS MATA, 2009(semnasIF), 8-16.

Santosa, S., Widjanarko, A., \& Supriyanto, C. (2016). Model Prediksi Penyakit Ginjal Kronik Menggunakan Radial Basis Function, III(2), 2355-5920.

Sulistiyo, M. D. (2014). Iridology-Based Dyspepsia Early Detection Using Linear Discriminant Analysis and Cascade Correlation Neural Network, 139-144. 
Tahir, Z., Warni, E., Sylwana, E. A., \& Wahyuni, Q. (2012). Analisa Metode Radial Basis Function Jaringan Saraf Tiruan Untuk Penentuan Morfologi Sel Darah Merah ( Eritrosit ) Berbasis Pengolahan Citra, 6, 978-979.

Wijayanti, P. P., Dengen, N., Hairah, U., Informatika, T., Ilmu, F., Informasi, T., \& Mulawarman, U. (2017). DIAGNOSA GANGGUAN SARAF MELALUI CITRA IRIS MATA DENGAN METODE REGION OF INTEREST, 2(1). 